\title{
Study of SWOT Analysis Information System Mail and Logistic (MLO) Web-Based Application
}

\author{
Arum Puspita Ayu \\ Student of Magister Management of Information System \\ University Merdeka, Malang, East Java, Indonesia \\ ar.pusa8@gmail.com
}

\author{
Harianto Respati \\ Lecturer of Post-Graduate Department \\ University Merdeka, Malang, East Java, Indonesia \\ Dwi Arman Prasetya \\ Lecturer of Electrical Engineering Department \\ University Merdeka, Malang, East Java, Indonesia \\ arman.prasetya@unmer.ac.id
}

\begin{abstract}
Information technology becomes one of the important elements for an organization or company in realizing the effectiveness and efficiency of performance. To create a company that has a good performance, it requiring the existence of an information system to assisting the management in taking a decision. In its implementation, the use of information system still encounter some obstacles during the operation. In this study, the authors used application belongs to Mail and Logistic (MLO) agenpos application. Therefore, SWOT analysis is needed to know the strengths and weakness in internal factors and to know the opportunities and threats in external factors. Choosing the right strategy can maximize the strengths and opportunities, on the other side can minimize the weaknesses and threats.
\end{abstract}

Keywords - SWOT analysis, Mail and Logistic (MLO) Agenpos Application, Strategy, Internal Factors, External Factors

\section{INTRODUCTION}

The demands in getting information as fast as possible, the company continues to develop its information systems as a form of effort in making a strategy. Curry (2002) argues that humans, processes, and organizations are important factors in managing information systems effectively and efficiently. The main function of information is to reduce the risk and reduce uncertainty.

In the last few years, PT. Pos Indonesia (Persero) developed a franchise business called Agenpos Indonesia. Agenpos is a subsidiary of the company by placing small posts in various areas in order to facilitate consumers to send documents and goods easily and closely. The transactions of document and goods delivery using a web based application, Mail and Logistic (MLO) application. Remick (2011) argues that web based application is an application that using browser technology in running the application and it can only be accessed through a computer network. The advantage of web based applications is the existence of wide system access even though the server centralized at a central point.

The implementation of an information system that has been running will encounter several obstacles. Therefore, this study will discuss about how to make a strategy to reduce the obstacles by using SWOT analysis.

\section{LITERATURE REVIEW}

\section{A. SWOT Analysis}

SWOT analysis is an identification of various factors that are systematically used to formulate a corporate strategy (Freddy Rangkuti, 2009). SWOT analysis is based on a logic that maximize the strengths and opportunities but can minimize the weaknesses and threats at the same time. In the opinion of Kotler (2009), SWOT analysis is a way to observe market conditions through internal factors (SW) and external factors (OT). David (2006) compares the internal factors (SW) with external factors $(\mathrm{OT})$ :

1. Strengths including resources, skills, competitive advantage, and market needs.

2. Weaknesses including management capabilities, facilities of the company, financial resources, skills from the marketing, and brand image.

3. Opportunities including changes in technology, changes in competition and regulatory situations, good relationships between buyers-suppliers, etc.

4. Threats including slower market growth, technological changes, new revisions or regulations, and increased bargaining of key buyers-suppliers.

\section{B. Web-Based Information System}

According to James O'Brien (2014), system is a set of interrelated components among each other, with an obvious limitations and working together to achieve a goal. A system consists of a systems section (subsystem) as example, hardware and software. Each of these subsystems can consist of smaller subsystem called component. Subsystem of the hardware consists of input data, data processing, and output data. These subsystems are interconnected and mutually interact forming a unity in achieving a goal or purpose. Interaction of the subsystems are arranged in order to attained an integrated systems are not integrated and running in its own, then the purpose of the system will not be achieved. 
According to Tata Sutabri (2106), information defined as a result of the processing of data into a form that has the function to and more meaningful to the receiver of data by way of describing an event for real so it can be used as a decision making.

An understanding of information system is a set of components that are interconnected between one another that has a function in collecting information, process information, store information, and distribution information to support oversight and decision making within an organization or company (Kenneth C. Laudon and Jane P. Laudon, 2000). Information system is a combination of user and computer that manages change a data into information are stored (McKweon, 2002). Whitten et al. (2001) argues that the information system is the arrangement of data, activities, people, networks, and technology integrates with the aim to support and improve the day-to-day operations of an organization or company as well as for meet the needs of the information used for decision making or problem solving for managers.

Rouse (2011) argues that web-based information system is a program stored on the server and sent over the internet and accessed through the browser interface. The background concept of an application or web-based information system is an operation that involves the exchange of information (the client) with the computer as a provider of information (server). In detail, the server serves requests from clients which are just software called web server. Web server communicates with other software other commonly called middleware and these devices are associated with the database. The web-based application is a computer software encoded in a programming language that supports web-based software such as HTML, JavaScript, CSS, Python, PHP, CSS, Java, etc.

The advantages of web-based information system:

a. Web-based doesn't need to be installed on PC or laptop,

b. Doesn't require a license because it's the responsibility of the application provider,

c. Can run on any operating system,

d. Can be accessed in various media, and

e. Doesn't require computer with high specifications.

The disadvantages of web-based information system:

a. Requires a reliable and stable of intranet and internet connection, and

b. A good security system is required because the application is running centrally, if the central server are down, the application system can't operate.

\section{RESEARCH METHOD}

This study is a qualitative exploratory research using descriptive with the purpose to describe about SWOT analysis. The authors are analyzing the factors of Mail and Logistic (MLO) web-based application using SWOT analysis through systematic, factual, and accurate data. Huberman (1992) argues that qualitative descriptive is develop existing theories to simplify the data into a form that easier to read and interpreted by classification and categorization with supported by data that have been obtained or collected. The indicators of SWOT analysis on this study are: a. Internal factors ( $\mathrm{S}$ and $\mathrm{W})$

1) Resources,

2) Financing,

3) Internal advantages or disadvantages of organizational management, and

4) Organizational experiences.

b. External factors $(\mathrm{O}$ and $\mathrm{T})$

1) Government regulations,

2) Technological development,

3) Events, and

4) Environment

The type of data use in this study is primary data and secondary data. Primary data is the results data that obtained by researchers directly through interview and observation. Secondary data is the results from data that obtained from existing documentation.

In this study, the population is the user of Mail and Logistic (MLO) application especially on agenpos at Kepanjen, Malang area. The sample method that used by the researchers is purposive sampling. Purposive sampling is a method or technique in determining the sample for a particular purpose of the researcher (Sugiyono, 2002). The sample in this study is the informants were obtained by screening qualified individual to get the key informants who gave significant detail about Mail and Logistic (MLO) agenpos application.

\section{RESULT AND DISCUSSION}

\section{A. The Analysis of Strategic Value of Mail and Logistic (MLO) Application}

PT. Pos Indonesia (Persero) is an expedition company. The demand for a technological development, the competitiveness between companies is getting higher. Since Mail and Logistic (MLO) application are in operation, the changes are getting frequently because it has to adjust the growing of demands from competition among expedition companies. Mail and Logistic (MLO) application continue to innovate and to be evaluated for easier and better developments. There are some supporting and inhibiting factors:

1) Supporting factors

a) PT. Pos Indonesia (Persero) has been widely known by the public,

b) Supported by facilities and human resources,

c) Services from PT. Pos Indonesia (Persero) to makes it easy for customers, and

d) Information system Mail and Logistic (MLO) application has been integrated to the center.

2) Inhibiting factors

a) Application data is incomplete,

b) The use of limited websites in accessing Mail and Logistic (MLO) application, and

c) Many similar competitors.

\section{B. SWOT Analysis of Mail and Logistic (MLO) Application}

The following table is the SWOT calculation table based on internal factors and external factors. 
TABLE I. INTERNAL FACTORS EVALUATION MATRIX

\begin{tabular}{|c|l|c|c|c|}
\hline No & \multicolumn{1}{|c|}{ Strategic Factors } & Weight & Rank & Weight $\times$ Rank \\
\hline & Strengths & \multicolumn{2}{|l|}{} \\
\hline 1. & $\begin{array}{l}\text { Central integrated of } \\
\text { information system Mail and } \\
\text { Logistic (MLO) agenpos } \\
\text { application }\end{array}$ & 0,17 & 4 & 0,68 \\
\hline 2. & $\begin{array}{l}\text { Mail and Logistic (MLO) } \\
\text { agenpos application using } \\
\text { guidelines in the process of } \\
\text { data }\end{array}$ & 0,08 & 2 & 0,16 \\
\hline 3. & $\begin{array}{l}\text { Support from stakeholder or } \\
\text { management for Mail and } \\
\text { Logistic (MLO) application } \\
\text { development }\end{array}$ & 0,08 & 2 & 0,16 \\
\hline 4. & $\begin{array}{l}\text { There are facilities to } \\
\text { facilitate the submission of } \\
\text { related application } \\
\text { development }\end{array}$ & 0,08 & 2 & 0,16 \\
\hline Weaknesses & The data is incomplete & 0,125 & 3 & 0,375 \\
\hline 1. & $\begin{array}{l}\text { The limited use of the } \\
\text { browser to access the Mail } \\
\text { and Logistic (MLO) } \\
\text { application }\end{array}$ & 0,17 & 4 & 0,68 \\
\hline 3. & Takes time to process data & 0,125 & 3 & 0,375 \\
\hline 4. & $\begin{array}{l}\text { User can't access Mail and } \\
\text { Logistic (MLO) in offline } \\
\text { mode }\end{array}$ & 0,17 & 4 & 0,68 \\
\hline TOTAL & 1,00 & 24 & 3,27 \\
\hline
\end{tabular}

Table 1 describe about the evaluation of internal factors which shows that the result from SWOT analysis in internal factors on Mail and Logistic (MLO) agenpos application is $\mathbf{3 , 2 7}$. The score of internal factors will be applied in internal external matrix (IE Matrix).

TABLE II. EXTERNAL FACTORS EVALUATION MATRIX

\begin{tabular}{|c|c|c|c|c|}
\hline No & Strategic Factors & Weight & Rank & Weight $\times$ Rank \\
\hline & Opportunities & & & \\
\hline 1. & $\begin{array}{l}\text { PT. Pos Indonesia (Persero) } \\
\text { is already known by the } \\
\text { public at large so that } \\
\text { enough ease in finding } \\
\text { customers }\end{array}$ & 0,16 & 4 & 0,64 \\
\hline 2. & $\begin{array}{l}\text { Service delivery faster and } \\
\text { reliable because of } \\
\text { cooperation with large } \\
\text { enterprises }\end{array}$ & 0,12 & 3 & 0,36 \\
\hline 3. & Strategic locations & 0,12 & 3 & 0,36 \\
\hline 4. & $\begin{array}{l}\text { The number of consumers } \\
\text { who need the service } \\
\text { submissions quickly and } \\
\text { accurately within a definite } \\
\text { time }\end{array}$ & 0,08 & 2 & 0,16 \\
\hline & Threats & & & \\
\hline 1. & $\begin{array}{l}\text { Competitive tariff from } \\
\text { competitors }\end{array}$ & 0,12 & 3 & 0,36 \\
\hline 2. & $\begin{array}{l}\text { The number of private } \\
\text { expedition company of its } \\
\text { kind }\end{array}$ & 0,12 & 3 & 0,36 \\
\hline 3. & $\begin{array}{l}\text { Competition in the level of } \\
\text { service and facilities to the } \\
\text { customers }\end{array}$ & 0,16 & 4 & 0,64 \\
\hline 4. & $\begin{array}{l}\text { Promotional activities as } \\
\text { well as offer an innovative } \\
\text { and interesting service from } \\
\text { competitors }\end{array}$ & 0,12 & 3 & 0,36 \\
\hline \multicolumn{2}{|c|}{ TOTAL } & 1,00 & 25 & 3,24 \\
\hline
\end{tabular}

Table 2 describe about the evaluation of internal factors which shows that the result from SWOT analysis in internal factors on Mail and Logistic (MLO) agenpos application is $\mathbf{3 , 2 4}$. The score of internal factors will be applied in internal external matrix (IE Matrix).

After analyzing the internal and external factors, the next step is to make an internal - external matrix (IE Matrix). The purpose of this matrix is to learn the appropriate strategy that implement on Mail and Logistic (MLO) agenpos application.

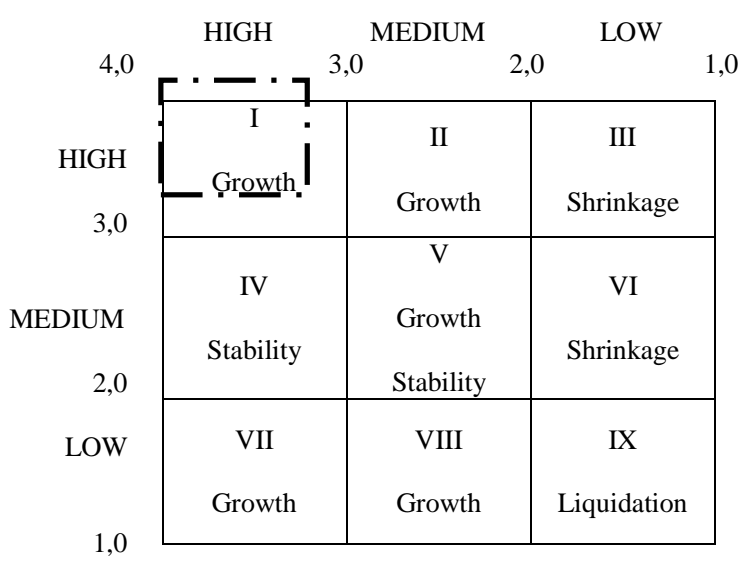

Fig. 1. Internal - External Matrix (IE Matrix)

Based on internal - external matrix above that Mail and Logistic (MLO) agenpos application is in a position of "growth". The factors of internal and external conditions on the matrix subsequently inserted into the SWOT matrix diagram that can be used to determine an appropriate strategy.

TABLE III. SWOT STRATEGy DIAGRAM OF MAIL AND LOGISTIC (MLO) APPLICATION

\begin{tabular}{|c|c|c|}
\hline EXTERNAL & 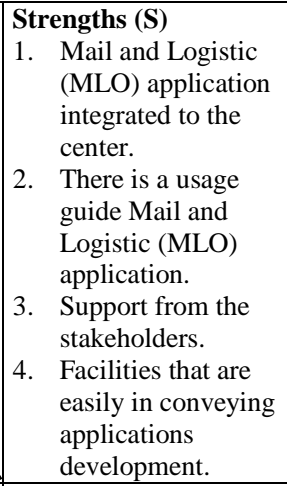 & $\begin{array}{l}\text { Weaknesses (W) } \\
\text { 1. Incomplete data. } \\
\text { 2. The limited use of } \\
\text { the browser to } \\
\text { access the Mail and } \\
\text { Logistic (MLO) } \\
\text { application. } \\
\text { 3. Takes time in } \\
\text { processing data. } \\
\text { 4. User can't access } \\
\text { Mail and Logistic } \\
\text { (MLO) in offline } \\
\text { mode. }\end{array}$ \\
\hline Opportunities (O) & SO Strategy & WO Strategy \\
\hline $\begin{array}{l}\text { 1. PT. Pos Indonesia } \\
\text { (Persero) is already } \\
\text { known by the } \\
\text { public at large so } \\
\text { that enough ease in } \\
\text { finding customers. } \\
\text { 2. Service delivery } \\
\text { faster and reliable } \\
\text { because of } \\
\text { cooperation with } \\
\text { large enterprises. } \\
\text { 3. Strategic locations. } \\
\text { 4. The number of }\end{array}$ & $\begin{array}{l}\text { 1. The application has } \\
\text { been integrated } \\
\text { with the center will } \\
\text { maximize the } \\
\text { delivery on time. } \\
\text { 2. Strategic locations } \\
\text { to ease the } \\
\text { customers. } \\
\text { 3. Need more support } \\
\text { from the } \\
\text { stakeholders to } \\
\text { maximize the } \\
\text { service. }\end{array}$ & $\begin{array}{l}\text { 1. Complete the data } \\
\text { in the application } \\
\text { in order to the } \\
\text { shipment of goods } \\
\text { can be on time. } \\
\text { 2. The application } \\
\text { can be used offline } \\
\text { as well as online to } \\
\text { ease the transaction } \\
\text { from customers. } \\
\text { 3. Minimize the time } \\
\text { of data processing. } \\
\text { 4. The ease of the use }\end{array}$ \\
\hline
\end{tabular}




\begin{tabular}{|c|c|c|}
\hline $\begin{array}{l}\text { consumers who } \\
\text { need the service } \\
\text { submissions } \\
\text { quickly and } \\
\text { accurately within a } \\
\text { definite time. }\end{array}$ & $\begin{array}{l}\text { 4. Improve facilities } \\
\text { on application } \\
\text { development in } \\
\text { order to cooperate } \\
\text { well between } \\
\text { agenpos and the } \\
\text { center. }\end{array}$ & $\begin{array}{l}\text { of the browser so } \\
\text { that the resulting } \\
\text { service is } \\
\text { unlimited. }\end{array}$ \\
\hline $\begin{array}{l}\text { Threats }(\mathbf{T}) \\
\text { 1. Competitive tariff } \\
\text { from competitors. } \\
\text { 2. The number of } \\
\text { private expedition } \\
\text { company of its } \\
\text { kind. } \\
\text { 3. Competition in the } \\
\text { level of service and } \\
\text { facilities to the } \\
\text { customers. } \\
\text { 4. Promotion by the } \\
\text { competitors. }\end{array}$ & $\begin{array}{l}\text { ST Strategy } \\
\text { 1. Improve the service } \\
\text { of delivery system } \\
\text { that is integrated to } \\
\text { the center. } \\
\text { 2. Compare the tariff } \\
\text { between companies } \\
\text { of its kind to attract } \\
\text { consumer interest. } \\
\text { 3. Promote better } \\
\text { service to the } \\
\text { customers. } \\
\text { 4. Promote innovative } \\
\text { promotions to } \\
\text { attract consumers. }\end{array}$ & $\begin{array}{l}\text { WT Strategy } \\
\text { 1. Provide shipping } \\
\text { service offline. } \\
\text { 2. Minimize the time } \\
\text { of data processing. } \\
\text { 3. The company has } \\
\text { rates that compete } \\
\text { to others but better } \\
\text { delivery service. } \\
\text { 4. Improve the } \\
\text { quality of services } \\
\text { and facilities. }\end{array}$ \\
\hline
\end{tabular}

\section{CONCLUSION}

Based on the results of analysis and discussion, then the conclusions from the analysis of Mail and Logistic (MLO) agenpos application is as follows:

A. Factors that support internal of Mail and Logistic (MLO) application

1) The application already integrated to the center,

2) There is a usage guide in using the Mail and Logistic (MLO) agenpos application through training that has been served by PT. Pos Indonesia (Persero), and

3) Support from the stakeholders in improving the services of Mail and Logistic (MLO) application development.

B. Factors that support external of Mail and Logistic (MLO) application

1) PT. Pos Indonesia (Persero) is already known by the public at large so that enough ease in finding customers,

2) Services deliveries more quickly and reliably within the country through cooperation with large enterprises,

3) The number of market share or a business customer in need of service delivery of timely,

4) Accurate within a definite period of time, and

5) Strategic location.
C. Factors that restricting of Mail and Logistic (MLO) application

1) Incomplete data,

2) The limited use of the browser to access Mail and Logistic (MLO) application,

3) Takes time in processing data,

4) The Mail and Logistic (MLO) is not accessible for offline mode,

5) The number of private expedition company of its kind, and

6) Competition in the level of service and facilities to the customers.

\section{REFERENCES}

[1] Al-Mamary, Yaser Hasan, Alina Shamsuddin, and Nor Aziati. (2014). The Relationship between System Quality, Information Quality, and Organizational Performance. International Journal of Knowledge and Research in Management and E-Commerce vol. 4, issue 3.

[2] Alkhattabi, Mona, Daniel Neagu, and Andrea Cullen. Information Quality Framework for E-Learning Systems. Knowledge Management and E-Learning: An International Journal vol. 2 no. 4, p. 340.

[3] Burton, Swanson and Neil C. Ramiller. (2004). Innovating Mindfully with Information Technology. MIS Quarterly vol. 28 no. 4 pp. 553-583.

[4] Dastgir, Mohsen and Ahmad S. Mortezaie. (2012). Factor Affecting The End-User Computing Satisfaction. Business Intelligence Journal vol. 5 no. 2.

[5] Frenzel, Carroll W. (1996). Management of Information Technology. Boyd \& Fraser Publishing Company, USA.

[6] Karim, Akram Jalal. (2011). The Significance of Management Information Systems for Enhancing Strategic and Tactical Planning. Journal of Information Systems and Technology Management vol. 8 no. 2, p. 459-470.

[7] Knight, Shirlee-Ann and Janice Burn. (2005). Developing A Framework for Assessing Information Quality on the World Wide Web. Informing Science Journal volume 8

[8] Nowduri, Srinivas. Management Information Systems and Business Decision Making: Review, Analysis, and Recommendations. Journal of Management and Marketing Research.

[9] Skyrius, Rimvydas, Gelyte Kazakeviciene, and Vytautas Bujauskas. (2013). From Management Information Systems to Business Intelligence: The Development of Management Information Needs. International Journal of Artificial Intelligence and Interactive Multimedia vol. 2 no. 3 . 